\title{
DEVELOPMENT AND VALIDATION OF THE MODIFIED FALLS EFFICACY SCALE INDONESIAN VERSION
}

\author{
Anastasia Putu Martha Anggarani, Raditya Kurniawan Djoar
}

STIKES Katolik St. Vincentius a Paulo Surabaya, Jl.Jambi 12 Surabaya

\begin{abstract}
Fear of falling causes a decrease quality of life of elderly. Tool for identified fear of falling is Modified FES I adopted from FES I. FES-I needs to be developed because it's used for people with disabilities so it's not sensitive to assess fear of falling in elderly. Content validation and internal consistency of tools need to be done. Original instrument was translated into Bahasa by two linguists and health professionals. Translation results were translated back into English by two other translators. After considering language equality, content validity was tested by 7 geriatricians (physiotherapists, lecturers and doctors). 105 elderly ( \pm 76 years old) in nursing homes were selected by proportional random sampling. Validity index (CVI) and Cronbach's alpha are used to analyze the questionnaire. Modified FES-I contains 16 items. CVI results was $>0.8$ for item level and $>0.9$ for the entire questionnaire. Questions 1,3,4,5,10, and 11 need to be modified according to the culture and conditions in Indonesia and 12 need to be modified because it overlaps with number 11 . Internal consistency is very good (0.957). The results showed, Modified FES-I is valid and can be used to measure fear of falling in elderly in Indonesia
\end{abstract}

Keywords: elderly, Modified FES I, validation

\section{ABSTRAK}

Takut jatuh menyebabkan penurunan kualitas hidup lansia. Alat ukur identifikasi takut jatuh lansia adalah Modified Falls Eficacy Scale Indonesian Version (FES I) yang diadopsi dari Falls Efficacy Scale International (FES I). FES-I perlu dikembangkan karena digunakan untuk kegiatan penyandang cacat sehingga kurang peka menilai takut jatuh lansia. Agar dapat digunakan, perlu dilakukan validasi konten dan konsistensi internal alat ukur. Langkahnya, instrument asli (16 item) diterjemahkan ke Bahasa Indonesia oleh dua ahli bahasa dan professional kesehatan. Hasil terjemahan diterjemahkan kembali ke Bahasa Inggris oleh dua penerjemah lain. Setelah mempertimbangkan kesetaraan bahasa, validitas konten diuji 7 ahli geriatri (fisioterapis, dosen fisioterapi dan dokter).Sebanyak 105 (usia rata-rata= 76 tahun) di panti jompo dipilih dengan proportional random sampling. Indeks validitas (CVI) dan alpha Cronbach digunakan untuk menganalisis validitas konten dan konsistensi internal kuesioner. Modified FES-I mengandung16 item. Hasil CVI yaitu $>0,8$ untuk item level dan $>0,9$ untuk keseluruhan kuesioner. Saran ahli, pertanyaan nomor 1, 3, 4, 5, 10, dan 11 perlu dimodifikasi sesuai budaya dan keadaan di Indonesia dan nomor 12 dimodifikasi karena tumpang tindih dengan nomor 11 . Konsistensi internal sangat baik (alpha Cronbach $=0,957$ ). Hasil penelitian menunjukkan bahwa Modified FES-I valid dan dapat digunakan untuk mengukur takut jatuh lansia di Indonesia

Kata kunci: Iansia, Modified FES I, validasi 


\section{INTRODUCTION}

The aging process causes a decrease in physical ability which can result in falls in the elderly (Narinder, Kaur, Multani \& Verma, 2007). The number of falls in the elderly is quite high, with at least $28-35 \%$ of people aged 65 years experiencing falls each year and that number increases to $32-42 \%$ for the elderly when aged 70 years (World Health Organization, 2007). Falling events are influenced by several factors, one of which is a personal factor which is fear of falling (Shaw, 2010). Fear of falling inhibits the quality of life of the elderly and increases the risk of falling through a reduction in physical activity, confidence, strength and balance (Artin et al., 2005). Fear of falling results in reduced balance control and reduced self-confidence to prevent falls, which will further increase the incidence of falls in the elderly (Public Health Agency of Canada, 2005). One solution to reduce the fear of falling is to identify the fear of falling by using a measuring device that is appropriate to describe the fear of falling in someone, but currently there are no measuring instruments available to measure the fear of falling amongst the elderly when carrying out activities in Indonesia.

Fear of falling has caught the attention of the public health department in the last two decades (Lach, 2005). According to National Health Interview Surveyaround $26-55 \%$ of the elderly who live in the community in Asia experience fear of falling, and $40-73 \%$ of the elderly who have fallen, are afraid of falling. Fear of falling is the biggest fear, which is around $47 \%$ elderly and this condition is more common in women than men (Barry et al., 2014). One study, which was conducted on 1000 women for more than 3 years, discovered that more than one third of the women reported experiencing a fear of falling and experienced an increase in the fear by $45 \%$ after 3 years (Lach, 2005).

Fear of falling is an excessive fear of falling over, which results in restrictions on motion when performing functional activities. With these restrictions, it can cause deconditioning and ultimately increase the risk of falling (Shaw, 2010).
Fear of falling can also result in restrictions on social interactions and cause anxiety (Austin, Devine, Dick, Prince, \& Bruce, 2007). The increasing numbers of elderly who fear falling has resulted in a decrease in the independence of the elderly in their daily activities, a decrease in the quality of life of the elderly and a decrease in their social interactions (Murphy, 2002). This change results in the loss of selfconfidence in maintaining balance when walking (Greenberg \& A, 2011).

To identify the fear of falling in the elderly, one measure that can be used is the Modified Falls Efficacy ScaleIndonesian Version (modified FES I). Modified FES I was adopted from the Falls Efficacy Scale International (FES I). Some experts suggested developing FES-I because the items in the original FES-I were designed for people with disabilities and were therefore less appropriate to assess the fear of falling in active elderly people and it also needed to be further developed to adjustto an alternative situation and culture (Yardley et al., 2005)

\section{METHOD}

A total of 105 respondents were recruited in this study using proportional random sampling. The researcher used various methods to ensure the respondents were varied in terms of age, gender, economic background, level of physical function and medical history. The validity test in this study uses content validity while the reliability test of this study uses the Cronbach alpha formula.

Validation of the questionnaire began with the translation process of the questionnaire using a sworn translator. Questionnaires translated into Indonesian were then translated back into English. After that, the questionnaire was sent to the experts to assess the similarity of the meaning of the sentences between the original questionnaire and the translated questionnaire. In this process, the results of item number 15 needed to be adjusted according to the sentence. The question item 'goes up or down the slope'was then adjusted to 'walk up or down the slope'. In addition, there are differences in the meaning of concerned words which are interpreted as caring and worried. The 
researcher decided to choose one of the meanings in the language, namely worry. After the process was completed, the content of the questionnaire was corrected by 7 experts. Next, the researcher compiled a questionnaire based on the input obtained. After the questionnaire was compiled, the questionnaire was tested on 105 elderly people at PantiWredha Bhakti LuhurSidoarjo. Elderly people were asked to fill out questionnaires in accordance with the instructions by giving a check mark to the column that represented the feeling of fear of falling in the elderly when carrying out the activities listed on the questionnaire. Scoring in this questionnaire was as follows: not at all concerned $=1$, somewhat concerned $=2$, fairly concerned $=3$, very concerned $=4$ with the highest total score being 64 and the lowest being 16 . If the overall value produced was 16-19 this meant a low concern, if it was 20-27 this meant a moderate concern and if it was $28-64$ this meant a high concern.

\section{RESULT}

Based on the correction of content by 7 experts, it was found that Item content validity (I-CVI) was in the range of 0.857 - 1 (valid value $>0.78$ ), while for the Sum-Content Validity Index (S-CVI) it was 0.93 (value valid> 0.9) with the following description:

approach, probably due to its purpose that wanted to review anaemia in pregnancy and its related factors. Studies were mostly carried out in Java Island because Java is the central of Indonesian development. It is supposed that researches are done in other area. All researches sample was pregnant women, and there had not been a research that reviewed possible factors that influenced anaemia in pregnant women from different perspectives, such as family, health workers, or community (community leader or health cadre). Details of articles are presented in table 1.

Table 1. Content Validity

\begin{tabular}{|c|c|c|c|}
\hline No & Activity & Result & CVI \\
\hline 1 & $\begin{array}{l}\text { Cleaning the house (e.g. sweeping, } \\
\text { vacuuming or dusting) }\end{array}$ & $\begin{array}{l}1 \text { expert considered somewhat } \\
\text { relevant. Suggestion : 'vacuuming' } \\
\text { removed }\end{array}$ & $\begin{array}{l}6 / 7= \\
0.857\end{array}$ \\
\hline 2 & Getting dressed or undressed & $\begin{array}{l}1 \text { expert considered somewhat } \\
\text { relevant. }\end{array}$ & $\begin{array}{l}6 / 7= \\
0.857\end{array}$ \\
\hline 3 & Preparing simple meals & $\begin{array}{l}1 \text { expert considered somewhat } \\
\text { relevant. } 1 \text { expert considered not } \\
\text { relevant. } \\
\text { Suggestion : replaced by "cooking in } \\
\text { the kitchen" }\end{array}$ & $\begin{array}{l}5 / 7= \\
0.714\end{array}$ \\
\hline 4 & Taking a bath or shower & $\begin{array}{l}\text { Suggestion : replaced by "Take a } \\
\text { shower in a standing position" }\end{array}$ & $7 / 7=1$ \\
\hline 5 & Going to the shop & $\begin{array}{l}\text { Suggestion : replaced by "Shop at the } \\
\text { market" }\end{array}$ & $7 / 7=1$ \\
\hline 6 & Getting in or out of a chair & $\begin{array}{l}\text { Suggestion : replaced by "Sitting to } \\
\text { standing or standing to sitting" }\end{array}$ & $7 / 7=1$ \\
\hline 7 & Going up or down stairs & & $7 / 7=1$ \\
\hline 8 & $\begin{array}{l}\text { Walking around in the } \\
\text { neighborhood }\end{array}$ & & $7 / 7=1$ \\
\hline 9 & $\begin{array}{l}\text { Reaching for something above your } \\
\text { head or on the } \\
\text { ground }\end{array}$ & Suggestion : refine the sentence & $7 / 7=1$ \\
\hline 10 & $\begin{array}{l}\text { Going to answer the telephone } \\
\text { before it stops ringing }\end{array}$ & $\begin{array}{l}2 \text { experts considered somewhat } \\
\text { relevant. Suggestion : replaced by } \\
\text { "walk fast" }\end{array}$ & $\begin{array}{l}5 / 7= \\
0.714\end{array}$ \\
\hline 11 & $\begin{array}{l}\text { Walking on a slippery surface (e.g. } \\
\text { wet or icy) }\end{array}$ & Suggestion : removed "e.g icy" & $7 / 7=1$ \\
\hline 12 & Visiting a friend or relative & $\begin{array}{l}1 \text { expert considered somewhat } \\
\text { relevant Added By Using Public } \\
\text { Vehicles }\end{array}$ & $\begin{array}{l}6 / 7= \\
0.857\end{array}$ \\
\hline
\end{tabular}




\begin{tabular}{|c|c|c|c|}
\hline No & Activity & Result & CVI \\
\hline 13 & Walking in a place with crowds & $\begin{array}{l}\text { Suggestion : replaced by "Walk in the } \\
\text { crowd" }\end{array}$ & $7 / 7=1$ \\
\hline 14 & $\begin{array}{l}\text { Walking on an uneven surface (e.g. } \\
\text { rocky ground, poorly maintained } \\
\text { pavement) }\end{array}$ & & $7 / 7=1$ \\
\hline 15 & Walking up or down a slope & $\begin{array}{l}1 \text { expert considered somewhat } \\
\text { relevant. }\end{array}$ & $\begin{array}{l}6 / 7= \\
0.857\end{array}$ \\
\hline 16 & $\begin{array}{l}\text { Going out to a social event (e.g. } \\
\text { religious service, family gathering, } \\
\text { or club meeting) }\end{array}$ & & $7 / 7=1$ \\
\hline
\end{tabular}

Respondents consisted of 105 elderly people at Bhakti Luhur, Hargodedali and St. Yosef Nursing Home Surabaya. They were $70 \%$ female with an age of about 76 years old.

Table 2. Respondents Characteristics

\begin{tabular}{lll}
\hline Variable & $\begin{array}{l}\text { Sub } \\
\text { Group }\end{array}$ & $\begin{array}{l}\text { Total } \mathbf{n}=105 \\
\text { Mean } \pm \text { SD/n } \\
(\%)\end{array}$ \\
\hline Age (Years) & Male & $\begin{array}{l}76,3 \pm 8,02 \\
31(29,5 \%)\end{array}$ \\
Gender & Female & $74(70,5 \%)$ \\
\hline
\end{tabular}

The results of the reliability of this measuring instrument were obtained from the data, which was processed using the Cronbach's Alpha formula which is $\mathbf{0 . 9 5 7}$ (table 3).

\begin{tabular}{cc}
\multicolumn{2}{c}{ Table 3. Reliability Statistics } \\
\hline $\begin{array}{c}\text { Cronbach's } \\
\text { Alpha }\end{array}$ & N of Items \\
\hline .957 & 16 \\
\hline
\end{tabular}

\section{DISCUSSION}

This study involved experts who were used to validate the questionnaires, by giving input on each sentence point in the questionnaire. Point number 1 is "Cleaning the house (e.g. sweeping, vacuuming or dusting)", the CVI value is 0.857 . This activity is still included because this activity is a dual task that requires the ability to maintain balance whilst holding a cleaning device and standing, walking or squatting. There was an input to eliminate the word "vacuuming" because these activities are rarely carried out in Indonesia when cleaning houses. Indonesia is a country that has a tropical climate and therefore Indonesian homes are mainly made of ceramics, wood, and land and no carpet is needed to keep warm (Suerni, 2013).
Point question number 3 "Preparing simple meals" CVI value is 0.714 . The input for this point is to replace the phrase "Preparing simple meals" with "cooking in the kitchen" because cooking activities for Indonesians are almost always done in the kitchen (Putra, 2013). The staple food of Indonesian people is rice. Rice is consumed by Indonesians for breakfast, lunch and dinner. Indonesians always use the kitchen to produce their dishes. So, Indonesians do not distinguish between simple food and the main food. Cooking in the kitchen is a complex activity (Satriana, 2009). The floor is slippery because of oil and there is fire as well as sharp objects and heavy kitchen equipment aroundtherefore it is an environment that requires people to be careful not to fall. If someone has lost the ability to maintain balance, that person would be afraid of falling while doing activities in the kitchen.

Point question number 5 "Going to the shop", the value of CVI is 1 . Indonesian shopping activities are carried out in several types of places. Shopping places in Indonesia are markets, supermarkets, grocery stores, and mobile vegetable vendors. Each shopping place has a different kind of character. So, for this point the question needed to be changed to be more specific about the place of shopping because fear of falling is also influenced by a person's ability to adjust to activities in a particular environment (Skelton, 2017).

Point question number 4 "Taking a bath or shower", the CVI value is 1 . Bathing with showers is rarely done by Indonesians. Indonesian people are in the habit of bathing using a bailer (Suhardi, 2014). When taking a bath, which affects people feeling down is the standing 
position on the wet floor not because the toiletries are used. So, the sentence in question number 4 is replaced by "Take a shower in a standing position" to clarify the meaning of the question.

Question number 10, which is "Going to answer the telephone before it stops ringing", has a CVI value of 0.714 . In this era, traditional telephone usage has been reduced and replaced with mobile phones that are easy to carry (Yasser, 2016). For this question, what is more emphasized is how to pick up the phone before it stops ringing, namely by walking fast. So, this question is replaced with a sentence with "walk fast" in it to better represent the meaning of the sentence in question.

Point question number 11 is "Walking on a slippery surface (e.g. wet or icy)" and has a CVI value of 1 . Indonesia is a tropical country that has 2 seasons. In Indonesia, there is only one place where there is snow and the place is not a residential area (Aldrian, 2001). So this sentence is adjusted to this situation by eliminating the word "ber-es".

Point question number 12 "Visiting a friend or relative" has a CVI value of 0.857 . These activities overlap with question number 16 "Going out to a social event (e.g. religious service, family gathering, or club meeting)". This activity was changed by adding the transportation equipment used to travel. When the elderly use public transportation, the concern would be their ability to maintain balance when starting to step into the vehicle, maintainingtheir balance in the vehicle, and then when disembarking from a vehicle that can run at any time.

\section{CONCLUSION}

This study states that the Modified FES I isa valid and reliable tool to measure the fear of falling in the elderly. The modified FES I isshort and easy to use and therefore the best measurement tool to use to measure the level of fear of falling during social and physical activities inside and outside the room. The modified FES I has 16 question items with answer choices in the form of a Likert scale. Elderly people were asked to fill out answers according to the scale that represents itself based on the activities listed on the measuring instrument. This measuring instrument has been tested with a good level of validity (I-CVI $0.857-1$ and S-CVI 0.93) and Cronbach alpha reliability 0.957 .

\section{REFERENCES}

Aldrian, E. (2001). Pembagianiklim Indonesia berdasarkan pola curah hujan dengan metode "double correlation". Jurnal Sains dan Teknologi Modifikasi Cuaca, 3, 11.

Artin, F. I. C. M., Art, D. E. H., Pector, T. I. M. S., Oyle, D. A. V. D., Arari, D. A. H., \& Martin, F. C. (2005). Fear of falling limiting activity in young-old women is associated with reduced functional. Age and Ageing, 34, 281287. https://doi.org/10.1093/ageing/ afi074

Austin, N., Devine, A., Dick, I., Prince, R., \& Bruce, D. (2007). Fear of falling in older women: A longitudinal study of incidence, persistence, and predictors. Journal of the American Geriatrics Society, 55(10), 15981603. https://doi.org/10.1111/j.15325415.2007.01317.x

Barry, E., Galvin, R., Keogh, C., Horgan, F., Fahey, T., Tinetti, M., Kivela, S. (2014). Is the Timed Up and Go test a useful predictor of risk of falls in community dwelling older adults: a systematic review and metaanalysis. BMC Geriatrics, 14(1). https://doi.org/10.1186/1471-231814-14

Greenberg, S., \& A. (2011). Assessment of fear of falling in older adults: The Falls Efficacy Scale-International (FES-I). Hartford Institute for Geriatric Nursing, 45(29).https://doi. org/10.1159/000320054.Kempen

Lach, H. W. (2005). Incidence and risk factors for developing fear of falling in older adults. Public Health Nursing, 22(1), 45-52. 
Murphy, S. L. (2002). Characteristics associated with fear of falling and activity restriction in communityliving older persons. Journal of American Geriatric Society, 50 (3).

Narinder Kaur Multani, \& Verma, S. K. (2007). Principles of Geriatric Physiotherapy. Retrieved from http://books.google.com/books?id=H ATDTIKq0GUC\&pgis $=1$

Public Health Agency of Canada. (2005). Report on seniors' falls in Canada. Canada: Minister of Public Works and Government Services Canada.

Putra, M. F. (2013). Model Dapur Masakan Tradisional Khas Kota Malang Dengan Konsep Open Kitchen (15th ed.). Jakarta: RUAS.

Satriana, P. (2009). Perbandingan Dapur Terbuka Tradisional dan Modern di Indonesia. Retrieved April 12, 2019, from http://lib.ui.ac.id/file?file=digital/ 20249527-R050944.pdf: http://lib.ui. ac.id/file?file=digital/20249527-R050 944.pdf

Shaw, G. B. (2010). Fear of Falling and Anxiety. Retrieved from http://www. cato-unbound.org/2010/04/07/Richa rdthaler/fear-of-falling/
Skelton, T. (2017). Risk Factors for Falls. National Center for Injury Prevention and Control, 12.

Suerni, T. (2013).Desain Interior Rumah Minimalis (7th ed.). Jakarta: Kementrian Pendidikan dan Kebudayaan.

Suhardi, B. (2014). Desain Kamar Mandi Untuk Orang Lanjut Usia (Studi Kasus Panti Werdha Dharma Bakti). Seminar Nasional IDEC, 2. Surakarta: Universitas Sebelas Maret.

World Health Organization. (2007). WHO Global Report on Falls Prevention in Older Age WHO Global Report on Falls Prevention in Older Age. Perancis: WHO.

Yardley, L., Beyer, N., Hauer, K., Kempen, G., Piot-Ziegler, C., \& Todd, C. (2005). Development and initial validation of the Falls Efficacy ScaleInternational (FES-I). Age and Ageing, 34(6), 614-619. https://doi. org/10.1093/ageing/afi196

Yasser, A. (2016). Mobile phone: sejarah, tuntutan kebutuhan komunikasi, hingga prestise. Jurnal Ilmu Dakwah, 71 